\title{
REVEL Nicole (ed.), Songs of Memory in Islands of
}

Southeast Asia

Newcastle upon Tyne: Cambridge Scholars Publishing, 2013, 320 p.

\section{Catharine Mason}

\section{(2) OpenEdition}

Journals

Electronic version

URL: https://journals.openedition.org/clo/2432

DOI: $10.4000 /$ clo.2432

ISSN: 2266-1816

Publisher

INALCO

\section{Printed version}

Date of publication: 31 December 2015

ISBN: 9782858312276

ISSN: 0396-891X

\section{Electronic reference}

Catharine Mason, "REVEL Nicole (ed.), Songs of Memory in Islands of Southeast Asia", Cahiers de littérature orale [Online], 77-78 | 2015, Online since 10 May 2016, connection on 01 July 2021. URL: http:// journals.openedition.org/clo/2432 ; DOI: https://doi.org/10.4000/clo.2432

\section{(@) $(1) \Theta$}

Cahiers de littérature orale est mis à disposition selon les termes de la Licence Creative Commons Attribution - Pas d'Utilisation Commerciale 4.0 International. 


\section{Revel Nicole (ed.), 2013, Songs of Memory in Islands of Southeast Asia, Newcastle upon Tyne: Cambridge Scholars Publishing, 320 p.}

The collection of essays in Songs of Memory in Islands of Southeast Asia provides a rich source of descriptive, interpretive, and analytical data interpreted from a wide variety of disciplinary and methodological schemes. These studies formulate a remarkable volume of individual and collaborative studies of oral traditions within a particular geographical region.

A major strength of this collection as a whole results from the longstanding collaboration between its contributors along with their close working relations with local field associates. The vast quantity of data gleaned from archives, transcribed from the personal experience and accounts of community members, and observed in live performances by the book's authors is put forth in a coherent view of oral traditions practiced in South East Asian Islands, contributing to both synchronic and diachronic studies of linguistic and musical practices.

Revel divides the book's chapters into three parts that may be read as 1) collection techniques and the valorization of intangible cultural heritage; 2) analytical approaches to the interplay of voice, music, and the spoken/sung word; and 3) hermeneutics, or interpretive processes. The editor opens Part 1 with an essay by Fernando N. Zialcita who borrows from a theoretical framework of Gaston Bachelard to explore distinctly different levels of meaning that unfold in the experience of a traditional performance. Zialcita demonstrates how visual, aural, and vocal dynamics confer within a performance even for both listeners and speakers/singers. Comparative analysis of traditional material collected from a handful of traditions allows Zialcita to show how the dynamic cultural force of oral literary (intangible) heritage can serve to protect the tangible heritage of nature's landscapes and concrete monuments.

Leovino M. Garcia outlines thoughtful implications of Paul Ricœur's narrative theory to the interpretation and valorization of epics and ballads as historical narratives. Pointing to Ricœur's linking of poetics to ethics, Garcia argues for Ricœur's threefold mimesis (prefiguration, configuration, refiguration) as a process 
of human ethical capacity within an oral tradition. The experience of these three operations in the imagination of listeners to epics and ballads brings about a deep emotional transformation that carries essential ethical implications.

Nicole Revel shares the methodological and analytical highlights of her decades-long work with the Palawan of the Philippines. Her contribution to Songs of Memory focuses on the roles and functions of memory in oral tradition, more specifically the role of memory as an operation of the individual mind of the performer, as a set of codes that serve to organize a narrative, and as a function of the performance itself. A pioneer in applications of multi-media technology for archiving oral tradition, Revel provides an overview of the importance of this technology for scholars of oral tradition, and of her own applications in "The Philippine Epics and Ballads Multimedia Archive".

Dana Rappoport's detailed analysis of Toraja speech and songs brings together musical, stylistic, semantic, socio-cultural, symbolic, historical, and narrative data to demonstrate the essential inseparability of chants and rituals. Her analysis is both formal and functional. She provides detailed transcriptions of musical and literary forms and their interplay in performance as it evokes ritual meaning. Close analysis of several versions of the ossoran badong taken from an archival source and from her own field collection, provides a vivid description of the unfolding of performance as an integral part of its function as a rite of passage to new social status.

Aone van Engelenhoven illustrates the function of a "narrative artefact" -a term he coins to refer to "a device or object that plays a significant role in a story" - as working within the narrative structure ("topology" to use the author's term) to signal events linked to particular places, or as a means of connecting one narrative to another in the minds of the audience. He further elaborates upon the importance of narrative artefacts as indicators of a performer's competence, whether used to establish story settings or as mnemonic devices. Engelenhoven's interpretive analyses of stylistic, geographical, historical, symbolic, and cultural data identified in various episodes of the "Sailfish tales" as well as various other oral literary sources expands upon narratological approaches to verbal art.

Maria Christine Muyco's study of Panay Bukodon epic chanting pens Part 2 of Songs of Memory. Her work provides an enlightening analysis of Panay epic chanting as both technique and ideology. In a structural study of "vocal body" -involving the interweaving of words and musical forms as well as breathing based on aesthetic principles- the reader discovers a detailed cultural criteria of performance competence as they relate to expressivity and meaning. Muyco provides a substantial indigenous nomenclature as well as detailed descriptions related by a master Panay singer to show that the mastery of vocal style is intimately 
linked to an "ideology of expressivity" called sibod. The flow of breathing, singing, and storytelling is further linked to the understanding and experiencing of the Panay Bukidon culture.

Manolete Mora's study of the T'boli epic song also provides an indigenous nomenclature that serves to reveal community expectations of a ritual performance of epic. His linguistic and structural analysis of the Tubulul focuses on the structural roles of temporality in the narrative and its episodes as well as in the links between narrative and music. The author demonstrates the "ring form" (the return to the beginning point of the narrative at the narrative's end) as a formal process of the ritual meaning of the epic, namely renewal. Mora's analysis is quite thorough in that it provides an array of narrative details as they are linked to the narration (the performance) as well as the specific content of the epic as it relates to the psychosocial practice of transformation and reintegration.

Rosario B. S. Rosario describes intricate details of the traditional performances of the male-chanted Alim and the female-chanted Hudhud of the Ifugao as anchored in social norms of gender. Borrowing from analyses by Nicole Revel and Olivier Tourny, the author brings local singers to the forefront of his own analysis and unravels the key elements of vocals, words, and narrative content of both genres. Providing elaborate musical, discursive, stylistic, and socio-cultural data, Rosario shows how the Alim and the Hudhud serve as "gendered perspectives of the cultural and ethical tenets" of Ifugao society.

J. Ivanoff begins his essay with a list of paradoxes in the life of the Moken people and then shows how these paradoxes and their resolution are reflected as features of their oral literature. "Permeability and Resistance", he tells us, are part of the narrative fabric of epics and myths as well as a life strategy of cultural survival. Ivanoff provides an overview of oral literary genres -their forms, performance features, and functions- before moving on to specific performances as illustrations and essential features of two Moken oral tradition: syncretism of narrative speech and real world life, and the process of creation in performance as one of alternation. Ivanoff provides examples of how attempts to suppress the traditional ritual practices of the Moken have been met with effective resistance, thanks to creative transformation processes in which new objects and ideas become integral elements of the Moken value system.

The collection as a whole contains an interesting balance between empirical and theoretical approaches, enhanced by numerous cross-references of data gathered and analyzed among the group of 12 authors. Numerous diagrams, charts, and tables provide illustrative sketches and conceptual schemes for analytical models that should prove beneficial to comparative oral traditions on a global scale. 
272 Paroles publiques, paroles confidentielles $-\mathrm{n}^{\circ} 77-78$

The weakness of Songs of Memory reflects a general shortcoming of the wider field of vocal and verbal performance art studies, namely the lack of a conceptual or theoretical framework allowing for all oral tradition specialists, as well as outside scholars that could benefit from our findings, to readily access the data and the profound analyses presented by researchers. Our failure to identify in our publications definitions of terms such as "performance", "genre", and "style", to name but a few key concepts, will continue to marginalize an interdisciplinary field of study holding claim to a massive quantity of data that nonetheless remains wholly unsystematized. However, and despite the density of empirical data, the distinct differences in methodological and analytical approaches, and the patches of syntactic and rhetorical obscurity due to translation problematics of non-Anglophone research into English prose, the great strides of Nicole Revel and her authors to make a representative portion of their findings available in a single, English-language volume will surely prove valuable in the furthering of comparative oral tradition studies on an international level. 